University of Montana

ScholarWorks at University of Montana

Winter 2014

\title{
The Northwest Archivists Mentoring Program: A Case Study
}

\author{
Donna E. McCrea \\ University of Montana - Missoula, donna.mccrea@umontana.edu \\ Elizabeth A. Nielsen \\ Oregon State University, Elizabeth.Nielsen@oregonstate.edu \\ Anne Foster \\ National Park Service
}

Follow this and additional works at: https://scholarworks.umt.edu/ml_pubs

Part of the Library and Information Science Commons

Let us know how access to this document benefits you.

\section{Recommended Citation}

McCrea, Donna E.; Nielsen, Elizabeth A.; and Foster, Anne, "The Northwest Archivists Mentoring Program: A Case Study" (2014). Mansfield Library Faculty Publications. 19.

https://scholarworks.umt.edu/ml_pubs/19

This Article is brought to you for free and open access by the Mansfield Library at ScholarWorks at University of Montana. It has been accepted for inclusion in Mansfield Library Faculty Publications by an authorized administrator of ScholarWorks at University of Montana. For more information, please contact scholarworks@mso.umt.edu. 


\title{
The Northwest Archivists Mentoring Program: A Case Study
}

Donna E. McCrea, Elizabeth A. Nielsen, and Anne Foster

\begin{abstract}
The Northwest Archivists (NWA), a regional archival association in the Pacific Northwest, established a formal mentoring program in 2007. A pilot phase of the program ran for 2 years and included both formative and summative assessments from participants. This case study documents NWA's experiences designing and managing a mentoring program within a volunteer-run professional association, reflects on the program's successes and challenges, and recommends areas for future investigation.
\end{abstract}

(c) Donna E. McCrea, Elizabeth A. Nielsen, and Anne Foster. (cc) BY-NC

\section{KEY WORDS}

Mentoring, Mentoring Programs, Mentors, Protégés, Mentees, Professional Development, Archivists, Professional Associations 
$\mathrm{T}$ he Northwest Archivists, Inc. (NWA) is a regional association of professional archivists, users of archives, and others interested in the preservation and use of archival materials in the Pacific Northwest United States. ${ }^{1}$ NWA was established in the early 1970s and has about 200 members, primarily from Alaska, Idaho, Montana, Oregon, and Washington. As with other archival associations, NWA's individual members range from students in graduate-level archival programs to retired professionals. Some members are employed as full-time archivists, some have archival responsibilities as a fraction of their overall workload, and some are volunteers; their institutions range in size from a lone arranger shop to the National Archives and Records Administration. Some members do not work as archivists at all but have an interest in archival work, collections, or repositories. A board of elected volunteers governs NWA.

In 2007, NWA members voted to establish a formal mentoring program. This case study reports on the 2-year pilot phase of the program, including how the program was designed and administered, results of formative and summative assessments from participants, and lessons learned about managing a mentoring program within a professional association. The article ends with recommendations for additional areas of investigation.

\section{Context for this Case Study}

Mentoring is traditionally defined as a developmental relationship in which a more experienced person provides support and guidance to a less experienced person. Mentoring goes beyond a teacher-student relationship; mentors can serve as advisers, coaches, sounding boards, cheerleaders, and critics all rolled into one. Effective mentors give those with less experience an opportunity to improve their understanding of practices, to discuss problems, to analyze situations, and to learn from actions and mistakes in an atmosphere that is collaborative, constructive, and confidential. ${ }^{2}$ Having a mentor to share concerns with, bounce ideas off, and learn from can increase protégé self-confidence and facilitate taking on a new project or moving into a new role. Mentors can also benefit from mentoring relationships through the satisfaction that comes from contributing to the growth, knowledge, and skills of another individual, as well as through gaining or strengthening skills and abilities applicable to their own work. ${ }^{3}$

In 2006, several NWA members seeking mentors from within the association's region approached the NWA president. She tasked a member of the NWA governing board to investigate "whether to institute our own program or to work with SAA [Society of American Archivists] in some fashion to improve its mentoring program to better meet our members' needs." 4 The board member communicated with a number of current and former mentoring program 
coordinators, mentors, and protégés from regional and national archival and library mentoring programs, including the Society of California Archivists, the Society of American Archivists, and several sections of the American Library Association, to learn what did and did not work well within their programs. ${ }^{5}$ She also conducted a review of literature within the fields of library science, education, and organization management looking for best practices in designing mentoring programs, with an eye to mentoring programs within professional associations.

Literature reviews and bibliographies produced by Barbara Wittkopf, ${ }^{6}$ Lois J. Zachary, ${ }^{7}$ and Bonnie A. Osif ${ }^{8}$ about mentoring programs were useful starting points; Osif's in particular includes examples of successful mentoring programs in both academic and nonacademic settings. However, articles and monographs about developing mentoring programs largely focused on programs within a specific organization (such as a corporation or a library) or within a peer group working at the same institution (such as internal medicine physicians or tenure-track faculty). Most mentoring relationships described were supervisor-employee, senior employee-new employee, adult-youth, or teacher-student rather than peer-to-peer interactions; many were compulsory; and most assumed face-to-face interaction between mentor and protégé. Design of the NWA program was ultimately based on recommendations repeated across the literature and was particularly influenced by Norman Cohen's A Step-by-Step Guide to Designing an Effective Mentoring Program, ${ }^{9}$ Margo Murray's Beyond the Myths and Magic of Mentoring: How to Facilitate an Effective Mentoring Process, ${ }^{10}$ case studies in Wittkopf's Mentoring Programs in ARL Libraries: A SPEC Kit, ${ }^{11}$ and Lois Zachary's The Mentor's Guide: Facilitating Effective Learning Relationships. ${ }^{12}$

\section{Program Components}

In A Step-by-Step Guide to Designing an Effective Mentoring Program, Cohen stated that these questions must be answered before beginning a mentoring program:

- What are the primary goals of the program?

- Who should be targeted as participants?

- What are the objectives of the participants?

- What criteria and procedures will be used to conduct the match?

- What instruments and techniques will be used for assessment? ${ }^{13}$

The NWA board determined the program's goals should be to "contribute to the success of NWA members by facilitating individual growth; fostering a sense of community within the profession; encouraging thoughtful and meaningful engagement with issues; and developing competencies that strengthen 
the position of individuals, organizations, and programs in our ever-changing environment." ${ }^{14}$ Whereas professional association mentoring programs are typically focused on new members, ${ }^{15}$ the board determined that NWA's protégés need not be new members or new to the profession. In fact, NWA membership was not required for either mentors or protégés, though nonmembers would be encouraged to join. While the program did not specifically exclude graduate students, its intended purpose was to establish peer-to-peer relationships between practicing professionals.

The program was facilitated by a committee made up of 3 members appointed by the NWA president to 2-year terms and a coordinator ${ }^{16}$ selected by those 3 members for a 3-year term. The program coordinator was responsible for soliciting and accepting applications from potential mentors and protégés, facilitating pairings between mentors and protégés, troubleshooting any issues between pairs, and program assessment. All committee members played active roles in identifying and recruiting mentors and in determining appropriate pairings based on interests and skill sets. The committee chair submitted annual reports to the NWA board and managed the majority of publicity related to the program.

Calls for participation by protégés and mentors were made via the NWA newsletter, Easy Access, email announcements distributed to members by NWA state representatives, and at the NWA annual meetings. A web page with information about the program was created and linked to the NWA website. The mentoring program's website included an overview of the program and its goals, contact information, and application forms (see Appendices 1 and 2) that could be downloaded and either emailed or mailed to the program coordinator. Both formats were received. In their application, protégés were asked to articulate 1 to 3 specific areas on which they'd like to focus ${ }^{17}$ and were provided examples of potential focus areas such as the development of a skill, ability, or area of knowledge and understanding.

The NWA Mentoring Program operated in a "pilot phase" between 2007 and 2009. During the pilot, a total of 19 protégé applications were received; 14 mentor-protégé matches were made. Of the protégés not matched, 2 did not respond to follow-up queries by the program coordinator and appropriate mentors could not be found for 3 . Committee members actively recruited the majority of mentors, most often in response to a protégé's identified focus area(s) but occasionally based on geographic area. The program coordinator had a telephone conversation with each protégé applicant and each mentor to make or renew a personal connection and to gather additional information about interests and goals. Information from the application forms and personal conversations was shared with the committee during conference calls at which potential matches were discussed. 
When a potential mentor was identified for a protégé-and agreed to serve-the protégé was contacted, told about the mentor, and given the option of not accepting the match. ${ }^{18}$ A reason for not accepting the mentor was not required, but it was encouraged so that the program coordinator could try for a better match in the future. When both the mentor and protégé agreed to a match, the program coordinator sent them a formal email introducing them to each other and providing basic program logistics (such as that they would schedule their own first meeting). Attached to that introductory email was a document entitled "Fundamentals for Success" (see Appendix 3), which listed factors reported in the mentoring literature to increase the chances of a successful pairing. Pairs were matched for a year, but could formally dissolve the match at any time, without giving a reason, by contacting the program coordinator. ${ }^{19}$

A critical component of the NWA Mentoring Program was formative (midmatch) and summative (postmatch) assessment through surveys conducted with participants. ${ }^{20}$ Both the midmatch and the postmatch surveys were administered via SurveyMonkey and were sent to at least 2 pairs at a time to better allow respondents to remain anonymous to the committee and coordinator if they wished. The surveys used a combination of Likert-scale ("completely agree" through "completely disagree") and open-ended questions. Eleven protégés and eleven mentors received midmatch surveys (see Appendix 4) conducted between 8 and 12 months after their matches began. (Some minor revisions were made to the midmatch survey after the first round.) Eight mentors and seven protégés completed this survey, which was designed, in part, to help the committee gauge the effectiveness of announcements about the program, the procedures being used to make matches, and the coordinator's communication with the pairs.

The program coordinator officially closed each match by emailing the mentor and protégé about 13 months after the formal match was made. The email thanked the pair for participating in the pilot phase of the program and informed them that a postmatch survey would be administered after some time was allowed for reflection. Twelve mentors and twelve protégés completed a postmatch survey (see Appendix 5) conducted between 9 and 19 months after the official end of their match. This survey was designed to gauge participants' ongoing impressions about the program's strengths, weaknesses, and overall value, and to determine whether the program achieved its stated goals. ${ }^{21}$

\section{Program Evaluation}

Although the mentoring program was designed for yearlong matches, only half of the pairs met for a full 12 months. Of the other half, 3 pairs met for 2 to 4 months, 2 met for 4 to 6 months, and 2 had only 1 conversation. Sixty percent of the mentor-protégé meetings occurred by email, $30 \%$ by phone, and $10 \%$ in 
person. Despite the low number of in-person meetings, most pairs expressed a desire for at least one face-to-face meeting. While most protégés were satisfied with the amount of interaction they had with their mentors, many mentors felt they did not have as much time as they would have liked for mentoring. As one wrote, "The main prohibiting factor from my end was a lack of time. In hindsight I probably shouldn't have volunteered to serve as a mentor given the lack of availability in my schedule."

In matches that ended in less than 12 months, slightly more than half indicated that they had difficulty sustaining the relationship, while a nearly equal number felt that the goals of the mentorship had been successfully reached and the match was no longer needed. Though protégés were asked to list goals on their applications-and all protégés indicated in the postmatch survey that they generally or completely agreed that they had "one or more clear goals . . that was the focus of our interactions"-only $50 \%$ of mentors felt their protégés had clear goals for the partnership. More than one protégé suggested through the survey that they be provided with more resources and examples related to goal setting and working with a mentor. As one noted, "I didn't know how to utilize my mentor. I would have liked more suggestions on how to use the relationship." One mentor offered, "Maybe the mentor could be prompted to ask [about the protégé's goal or focus] if it isn't clear. In retrospect I wish I had asked.”

In a "pick as many as apply" question, both mentors and protégés were asked how they perceived the role of the mentors in the match. Of protégés, $42 \%$ felt their mentors had served in the role of teacher, although not a single mentor identified their role this way. One hundred percent of protégés and $90 \%$ of mentors viewed the mentor's role as that of resource. Thirty-six percent of mentors perceived themselves as advisors and $27 \%$ as counselors. In the words of one protégé, "Primarily, it was nice to have an experienced ear who was willing to listen and offer advice. As I am the only archivist at my library, and fairly new to the work, I really appreciated having someone I could trust to give me honest feedback about issues ranging from processing to advocating for my department to upper-level management."

Three-quarters of mentors and $70 \%$ of protégés completely or generally agreed that their mentoring partner was a good match. One-quarter of mentors indicated they were unsure if they were a good match; several expressed a desire for more resources about how to be a good mentor. One commented, "We had great conversations but only met about every 3-4 months. In other words, I am not sure if I did an OK job or not.”

Postmatch survey results indicated that most mentors and protégés felt that participating in the program was worth their time, and all respondents indicated that they would recommend the program to others. Most mentors and protégés indicated that the mentoring experience contributed to their own 
personal and professional growth, primarily by providing an opportunity for meaningful engagement with professional issues or through a stronger connection to a professional community. When asked if participating in the NWA Mentoring Program enhanced or improved their impression of NWA, 90\% of protégés indicated it did. This question was not asked of mentors, but in a survey of NWA members conducted in 2012 as part of a strategic planning process, respondents identified the Mentoring Program as a type of continuing education NWA does well, indicating that the program has support across the association. In the words of one member, "Though I have not participated, I think it's good that NWA has a formal mentoring program." 22

\section{Conclusion and Recommendations}

In many ways, the pilot phase of the NWA Mentoring Program was a success. The number of protégé applications received (nearly $10 \%$ of membership) indicated both an interest in and a need for a program that connects less experienced archivists with more experienced archivists. Among the program's goals was to contribute to the success of NWA members by "facilitating individual growth" and "developing competencies that strengthen the position of individuals, organizations, and programs in our ever-changing environment." Postmatch survey results indicated that the majority of respondents generally or completely agreed these goals had been met. In the words of one protégé, "Just talking with my mentor about the way she approached problems like mine in her own career and getting her advice was very assuring." Another noted, "My overall experience with this program was wonderful! It was nice to have someone with experience help me to grow in my first official 'job' out of grad school."

Among the program factors that worked well during the pilot was having a program coordinator. Serving as the "face" of the program in terms of direct interaction with applicants and recruits, the coordinator's work provided an overall impression of the organization as well as affecting the growth of individuals within the association. In the corporate environment, program coordination may be included in an employee's job description; in a volunteer-run professional association, the program coordinator must be able to dedicate sufficient time. The NWA Mentoring Program coordinator spent between 2 and 10 hours a month on the program during its pilot. Other factors that worked well included having a mentoring committee to help identify and recruit mentors and to evaluate the effectiveness of the program coordinator, having a "nofault," opt-out option for both mentors and protégés, communicating about the program in a variety of venues, and conducting formal evaluations. 
The NWA pilot also exposed a number of areas for improvement. Components that should be modified going forward include providing a structured orientation for both mentors and protégés. A formal orientation is a key element of many mentoring programs, especially in the corporate environment. As NWA lacked both the "in-house" expertise and the financial resources to hire a consultant, no such orientation program was developed. But it is apparent from the survey results that providing an orientation to both mentors and protégés at the front end of the match would enhance the overall effectiveness of the program. Identifying and providing access to appropriate publications, websites, and other resources about the mentoring process, as well as creating in-person and/or webinar-type orientations, may be areas in which NWA can collaborate with other archival associations, such as the Society of American Archivists, that also have or are developing mentoring programs. ${ }^{23}$

High-quality matches are fundamental to trust and relationship building, and therefore to mentoring program success. In addition to providing mentoring resources to pairs, more targeted questions in the application forms and by the program coordinator may ultimately result in better matches. One protégé noted that the program coordinator should ask "each mentor/protégé in advance of a match about their preferred methods of communication, and be sure to match people who had the same expectations of most convenient ways to connect." A periodic "check-in" with pairs by the program coordinator could also be beneficial. This check-in would allow either partner to seek feedback from the coordinator that could help to maintain the pair match, or indicate a mismatch early in the process. And, finally, a greater diversity of willing mentors (including skill sets, geographic location, and, potentially, ethnic background) would also facilitate more appropriate pairings.

One area needing particular attention is articulating the importance of relationship building. The survey results made clear that sustaining a mentoring relationship over the course of one year was very difficult for most participants. In some cases, this was due to the participant feeling his or her goals were met, but in other cases, the lack of a personal relationship was likely a contributing factor. As Lois Zachary noted, "the key to successful long-distance mentoring relationships is taking time to establish the human connection and develop a relationship." ${ }^{24}$ Although not taken into account during the design of NWA's mentoring program, a growing body of literature addresses strategies for success in electronic mentoring (e-mentoring) environments; this literature should be explored for its relevance to mentoring programs where in-person meetings are difficult to arrange, such as within professional associations. Technological tools such as video chat may also help to build more personal connections that could sustain a mentorship over a longer term. However, both the original interest in a regional (vs. a national) mentoring program and the postmatch survey results may indicate a need for NWA to provide more opportunities for in-person 
interaction and networking to enhance both formal and informal mentoring. At the least, the mentoring program should more strongly encourage face-to-face pair meetings. Early match endings likely also point to an interest in shortterm, focused learning opportunities.

Following the pilot phase, the mentoring committee recommended that the program be modified to accommodate short-term "micro-mentoring" pairings. The committee hoped that shorter, more focused mentorships would help protégés better identify a topic or goal to be addressed and would be useful for protégés who had a single, specific need for mentor guidance. For example, "micro-mentoring" might have been a good option for the job seekers who made up a larger number of protégé applicants as the economy worsened. Shorterterm mentorships may also lead to more mentor volunteers; several individuals who were asked to be mentors declined citing lack of time to participate, and others cited a lack of confidence in their ability to assist a protégé with all of his or her goals.

Mentoring program participants unanimously agreed that they would recommend the program to others, even if they, themselves would not participate again. One unexpected outcome of the NWA Mentoring Program is the goodwill the program fostered among the general membership, which includes many individuals who did not participate directly in the program as mentors or protégés. The results of the mentoring program's postmatch survey, as well as the NWA strategic priorities survey conducted in 2012, indicate strong support for an NWA Mentoring Program. Although fostering a sense of community within the profession was a stated goal of the program, enhancing members' perceptions of NWA itself was not articulated in advance. In the words of one mentor, "I believe the Mentoring Program to be an excellent component of NWA and that it reflects positively on the general collegiality which I feel is a major strength of NWA. I appreciate how proactive NWA is and this program demonstrates this in a visible manner." This support is an area worthy of attention by the association's leadership. For example, could missteps or a decision to discontinue the mentoring program result in a negative impression of NWA among the members? Or, conversely, could continuing to refine and enhance the program foster recruitment and retention of mentors and members?

Finally, although the initial function of program evaluations was to help determine whether the NWA Mentoring Program should continue, assessment must be an integral component of the program going forward. Future research should consider the long-term effects of the mentoring experience on the participants as well as the costs and benefits to the association itself and to the profession. ${ }^{25}$ Measuring the effectiveness of mentoring across the profession and for different demographics and constituencies would require coordination among the regional and national professional associations, but should provide insights beneficial to each program and to the profession as a whole. 


\section{Appendix 1-NWA Protégé Application Form}

\section{Protégé Application Form \\ Northwest Archivists, Inc.}

Mentoring can be defined as a developmental relationship in which a more experienced person provides support and guidance to a less experienced person. Working with a mentor gives a protégé the opportunity to improve his or her understanding of practices, discuss problems, and analyze and learn from mistakes in an atmosphere that is collaborative, constructive, and confidential.

In most successful mentoring relationships the protégé is able to articulate 1 or 2 specific goals for participation-these might involve the development of a skill, ability, or area of knowledge and understanding. Examples include but are not limited to:

- $\quad$ assistance with development of a new skill/competency

- feedback about the status of current competencies

- clarification or critique of career goals and/or professional progress

- discussion of selected readings/research

- exploration of new area of readings/research

- introduction to/referral through professional network

- discussion or critique of professional project(s)

- analysis of interpersonal skills, group dynamics, management skills

- reflections on personal values, job satisfaction, and career objectives

Please provide the following contact information:

Applicant's Name:

Title/Occupation:

Institution (if applicable):

Address:

Telephone:

Email:

Preferred method of contact: telephone email

To help facilitate an effective mentor/protégé match, please respond to the following:

1. Provide a brief summary of your relevant experience in the profession: ie. education, work experience, specialized skills, etc.

2. Indicate 1 to 3 areas you would like to focus on in your interactions with a mentor: 
3. It is recommended that at least 2 hours each month or 24 hours in one year be set aside for interaction specific to the mentoring relationship. Will it be possible for you to provide this time to the program? _ yes _ no

If no, please indicate the type/amount of time you could commit in a 12 month period:

4. If you consider yourself to be a member of an underrepresented group and you prefer your mentor to be a member of this group, please provide details that would help facilitate an appropriate match:

5. Are you currently an NWA member?

_ yes n no

Applicants who are not currently NWA members will be encouraged to join.

Email or mail your application to the NWA Mentoring Program Coordinator [contact information followed].

Thank you for your interest in participating in NWA's Mentoring Program! You will be hearing from the NWA Mentoring Program Coordinator soon. 


\section{Appendix 2-NWA Mentor Application Form}

\section{Mentor Application Form \\ Northwest Archivists, Inc.}

Mentoring can be defined as a developmental relationship in which a more experienced person provides support and guidance to a less experienced person. Mentoring goes beyond the traditional teacher-student relationshipeffective mentors serve as advisers, coaches, teachers, sounding boards, cheerleaders, and critics all rolled into one. Mentors give those with less experience an opportunity to improve their understanding of practices, discuss problems, and analyze and learn from mistakes in an atmosphere that is collaborative, constructive, and confidential.

NWA suggests that Mentors have at least five years of experience in the field, however exceptions may be made by the Program Coordinator.

Please provide the following contact information:

Applicant's Name:

Title/Occupation:

Institution (if applicable):

Address:

Telephone:

Email:

Preferred method of contact: __ telephone __ email

To help facilitate an effective mentor/protégé match, respond to the following:

1. Reason(s) for wanting to be a Mentor:

2. Provide a brief summary of your relevant experience: ie. education, work experience, specialized skills, etc.

3. Is there a particular area/aspect of the profession you would most like to work on with a protégé? If so, please provide details:

4. It is recommended that at least 2 hours each month or 24 hours in one year be set aside for interaction specific to the mentoring relationship. Will it be possible for you to provide this time to the program?

_ yes no no n

If no, please indicate the type/amount of time you could commit in a 12 month period: 
5. In response to demonstrated interested by our members, the NWA Mentoring Program will try to match members of underrepresented communities with members of similar background if requested. Do you consider yourself to be a member of an underrepresented group? (if so, please elaborate):

6. Are you currently an NWA member? yes no

Applicants who are not currently NWA members will be encouraged to join.

Email or mail your application to the NWA Mentoring Program Coordinator [contact information followed].

Thank you for your interest in serving as a Mentor in NWA's Mentoring Program! You will be hearing from the NWA Mentoring Program Coordinator soon. 


\section{Appendix 3-Fundamentals for Success}

\section{Fundamentals of a Successful Mentor/Protégé Relationship}

There are a number of factors which are known to increase the chances of success in a mentor/protégé relationship. These include:

- The mentor understands what he or she wants out of the mentoring relationship. The mentor can articulate his or her reasons for participating and how participation success will be measured.

- The protégé is able to articulate specific goals and expectations for participation. These might include the development of a skill, ability, or area of knowledge and understanding.

- Both mentor and protégé understand and agree that the topics and issues raised in their communication will primarily reflect the career and/or professional development interests of the protégé.

- Both mentor and protégé are prepared and willing to commit the time and energy necessary to make the relationship successful.

- Specific goals and expectations are established at the outset of the relationship (examples: how and when will parties communicate? what skills will be the focus for development?)

- Both mentor and protégé commit to participate as partners in a collaborative, interactive relationship.

- Both mentor and protégé strive to develop a relationship built on trust and respect and understand that it may take some time to get to this level.

- Both parties (but especially the mentor) commit to being/becoming good active listeners.

- The mentor is capable of recognizing and understanding protégé strengths and weaknesses in order to help that person, and understands how to balance praise with constructive criticism to facilitate protégé learning and development.

- Protégé expects and accepts constructive criticism as part of the learning process.

- Mentor knows when to let the mentoring relationship end-and may help the protégé find a new mentor for the next phase in his/her career.

- Both parties understand that confidentiality is essential to a productive mentoring relationship.

- Both parties agree up front to a "no fault" termination: the mentoring relationship may be ended at any time by either party without explanation or fault. 


\section{Appendix 4-NWA Mentoring Program Mid-Match Surveys}

\section{Mid-Match Mentor Survey}

I learned about NWA's Mentoring Program from: (check all that apply)

$\square$ The annual NWA meeting

$\square$ Easy Access (the NWA newsletter)

$\square$ A Mentoring Program Committee member (names here)

$\square$ NWA website

$\square$ Other

Indicate if you agree or disagree with the following statements:

\begin{tabular}{|l|l|l|l|l|}
\cline { 2 - 5 } \multicolumn{1}{l|}{} & & & & \\
\hline $\begin{array}{l}\text { The Mentoring Program application } \\
\text { process was easy to follow. }\end{array}$ & & & & \\
\hline $\begin{array}{l}\text { The Mentoring Program application asked } \\
\text { appropriate questions. }\end{array}$ & & & & \\
\hline $\begin{array}{l}\text { I heard from the Mentoring Program } \\
\text { Coordinator in a reasonable amount of } \\
\text { time after I submitted my application. }\end{array}$ & & & & \\
\hline $\begin{array}{l}\text { The Mentoring Program Coordinator asked } \\
\text { appropriate questions. }\end{array}$ & & & & \\
\hline $\begin{array}{l}\text { I was matched with a protégé within a } \\
\text { reasonable amount of time after I } \\
\text { submitted my application. }\end{array}$ & & & & \\
\hline $\begin{array}{l}\text { I would like more direction from/ } \\
\text { interaction with the Mentoring Program } \\
\text { Coordinator after the match is made. }\end{array}$ & & & & \\
\hline
\end{tabular}

On average I spend the following amount of time per month on the Mentoring Program (including planning for discussions, actual conversations, travel, etc.)
$\square$ Less than 1 hour
$\square$ 1-2 hours
$\square \quad 2.5-4$ hours
$\square$ 4.5-6 hours
$\square$ More than 6 hours 
This program takes:

$\square$ Too much of my time.

$\square$ The right amount of time to be beneficial for me and my protégé.

$\square$ Not enough time. I would like more interaction with my protégé.

$\square$ Other [free text box]

Indicate if you agree or disagree with the following statements:

\begin{tabular}{|c|c|c|c|c|c|}
\hline & 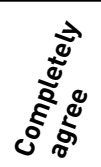 & 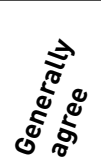 & ș & 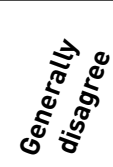 & 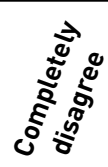 \\
\hline \multicolumn{6}{|l|}{$\begin{array}{l}\text { I am comfortable with the way my protégé } \\
\text { and I arrange appointments or conversa- } \\
\text { tions. }\end{array}$} \\
\hline \multicolumn{6}{|l|}{ My protégé and I are a good match. } \\
\hline \multicolumn{6}{|l|}{$\begin{array}{l}\text { I feel qualified to be a mentor to my } \\
\text { protégé. }\end{array}$} \\
\hline \multicolumn{6}{|l|}{$\begin{array}{l}\text { My protégé has clear goals on which he/ } \\
\text { she wants to work with a mentor. }\end{array}$} \\
\hline \multicolumn{6}{|l|}{$\begin{array}{l}\text { My protégé is making progress toward his/ } \\
\text { her goals. }\end{array}$} \\
\hline \multicolumn{6}{|l|}{$\begin{array}{l}\text { I trust that what I say to my protégé will } \\
\text { remain confidential. }\end{array}$} \\
\hline \multicolumn{6}{|l|}{ I enjoy working with my protégé. } \\
\hline \multicolumn{6}{|l|}{$\begin{array}{l}\text { Participating in the mentoring } \\
\text { program is rewarding for me. }\end{array}$} \\
\hline $\begin{array}{l}\text { I would recommend the NWA Mentoring } \\
\text { Program to others. }\end{array}$ & & & & & \\
\hline
\end{tabular}

Have you participated in a formal mentoring program in the past?

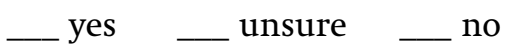

If participating in the NWA Mentoring Program has changed or enhanced your feelings about NWA in any way please tell us how: [free text box]

Because the NWA Mentoring Program is still in its "pilot phase," please tell us what other questions(s) should have been asked in this survey to gauge feedback about the program at this point in your match: [free text box]

Additional comments, ideas or suggestions: [free text box] 


\section{Mid-Match Protégé Survey}

I learned about NWA's Mentoring Program from:

$\square$ The annual NWA meeting

Easy Access (the NWA newsletter)

A Mentoring Program Committee member (names here)

Other

Indicate if you agree or disagree with the following statements:

\begin{tabular}{|l|l|l|l|l|l|}
\cline { 2 - 6 } \multicolumn{1}{l|}{} & & & & & \\
\hline $\begin{array}{l}\text { The Mentoring Program application } \\
\text { process was easy to follow. }\end{array}$ & (n) & & & \\
\hline $\begin{array}{l}\text { The Mentoring Program application asked } \\
\text { appropriate questions. }\end{array}$ & & & & & \\
\hline $\begin{array}{l}\text { I heard from the Mentoring Program } \\
\text { Coordinator in a reasonable amount of } \\
\text { time after I submitted my application. }\end{array}$ & & & & & \\
\hline $\begin{array}{l}\text { The Mentoring Program Coordinator asked } \\
\text { appropriate questions. }\end{array}$ & & & & & \\
\hline $\begin{array}{l}\text { I was matched with a mentor within a } \\
\text { reasonable amount of time after I } \\
\text { submitted my application. }\end{array}$ & & & & & \\
\hline
\end{tabular}

On average I spend the following amount of time per month on the Mentoring Program (including planning for discussions, actual conversations, travel, etc.)

$\square$ Less than 1 hour

$\square$ 1-2 hours

$\square \quad 2.5-4$ hours

$\square$ 4.5-6 hours

More than 6 hours 
Indicate if you agree or disagree with the following statements:

\begin{tabular}{|c|c|c|c|c|c|}
\hline & 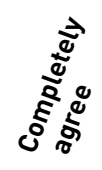 & 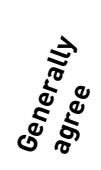 & $\frac{5}{5}$ & 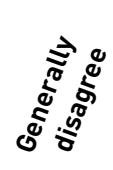 & 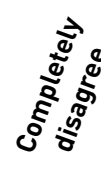 \\
\hline \multicolumn{6}{|l|}{$\begin{array}{l}\text { I am comfortable with the amount of time } \\
\text { this program takes. }\end{array}$} \\
\hline \multicolumn{6}{|l|}{$\begin{array}{l}\text { I am comfortable with the way my } \\
\text { mentor and I arrange appointments or } \\
\text { conversations. }\end{array}$} \\
\hline \multicolumn{6}{|l|}{ I enjoy working with my mentor. } \\
\hline \multicolumn{6}{|l|}{$\begin{array}{l}\text { My mentor has the appropriate } \\
\text { interpersonal skills to be a mentor. }\end{array}$} \\
\hline \multicolumn{6}{|l|}{$\begin{array}{l}\text { My mentor has the professional } \\
\text { abilities and skills to be a mentor. }\end{array}$} \\
\hline \multicolumn{6}{|l|}{ My mentor and I are a good match. } \\
\hline \multicolumn{6}{|l|}{$\begin{array}{l}\text { I set clear goal(s) on which to work with my } \\
\text { mentor. }\end{array}$} \\
\hline \multicolumn{6}{|l|}{$\begin{array}{l}\text { My mentor is helping me make progress } \\
\text { toward my goal(s). }\end{array}$} \\
\hline \multicolumn{6}{|l|}{$\begin{array}{l}\text { I trust that what I say to my mentor will } \\
\text { remain confidential. }\end{array}$} \\
\hline \multicolumn{6}{|l|}{ I enjoy working with my mentor. } \\
\hline \multicolumn{6}{|l|}{$\begin{array}{l}\text { Participating in the mentoring program is } \\
\text { rewarding for me. }\end{array}$} \\
\hline $\begin{array}{l}\text { I would recommend the NWA Mentoring } \\
\text { Program to others. }\end{array}$ & & & & & \\
\hline
\end{tabular}

Have you participated in a formal mentoring program in the past? _ yes unsure no

If participating in the NWA Mentoring Program has changed or enhanced your feelings about NWA in any way please tell us how: [free text box]

Because the NWA Mentoring Program is still in its "pilot phase," please tell us what other questions(s) should have been asked in this survey to gauge feedback about the program at this point in your match: [free text box] 


\section{Appendix 5-NWA Mentoring Program Post-Match Surveys}

\section{Post-Match Mentor Survey}

Did you maintain contact with your protégé (as part of the official mentorprotégé match) for the whole 12 months of the match?

_ yes _ no _ don't remember

If your mentor-protégé contact ended before one year, how long did the contact last?

$\square$ Never made contact

$\square 1$ conversation

1-2 months

$\square \quad 2-4$ months

$\square$ 4-6 months

$\square$ 6-11 months

If your mentor-protégé contact lasted less than 12 months, please indicate why (check all that apply).

$\square$ Unable to make or sustain contact with protégé

The protégé's goal or reason for wanting to work with a mentor was met or concluded

$\square$ The protégé's goal or reason for wanting to work with a mentor changed

$\square$ I (as mentor) was not a good match for the protégé's need

$\square$ I was unable to assist with the protégé's goal

$\square$ Other (please specify)

How many times did you talk with your protégé in your official role as mentor (i.e. times that had been scheduled for the purpose of a mentor-protégé conversation)?

$\square$ Only one time

$\square$ 2-4 times

$\square$ 5-10 times

$\square$ More than 10 times

Do you feel this number of interactions was sufficient to address your protégé's reason(s) for joining the Mentoring Program?

_ yes _ no _ unsure _ n/a

How did you conduct the majority of your mentor-protégé interactions?

$\square$ By email

$\square$ By telephone

In person

$\square$ Other (please specify)[free text box] 
Please share ideas about how the NWA Mentoring Program could better facilitate interactions between mentors and protégés. [free text box]

Indicate if you agree or disagree with the following statements:

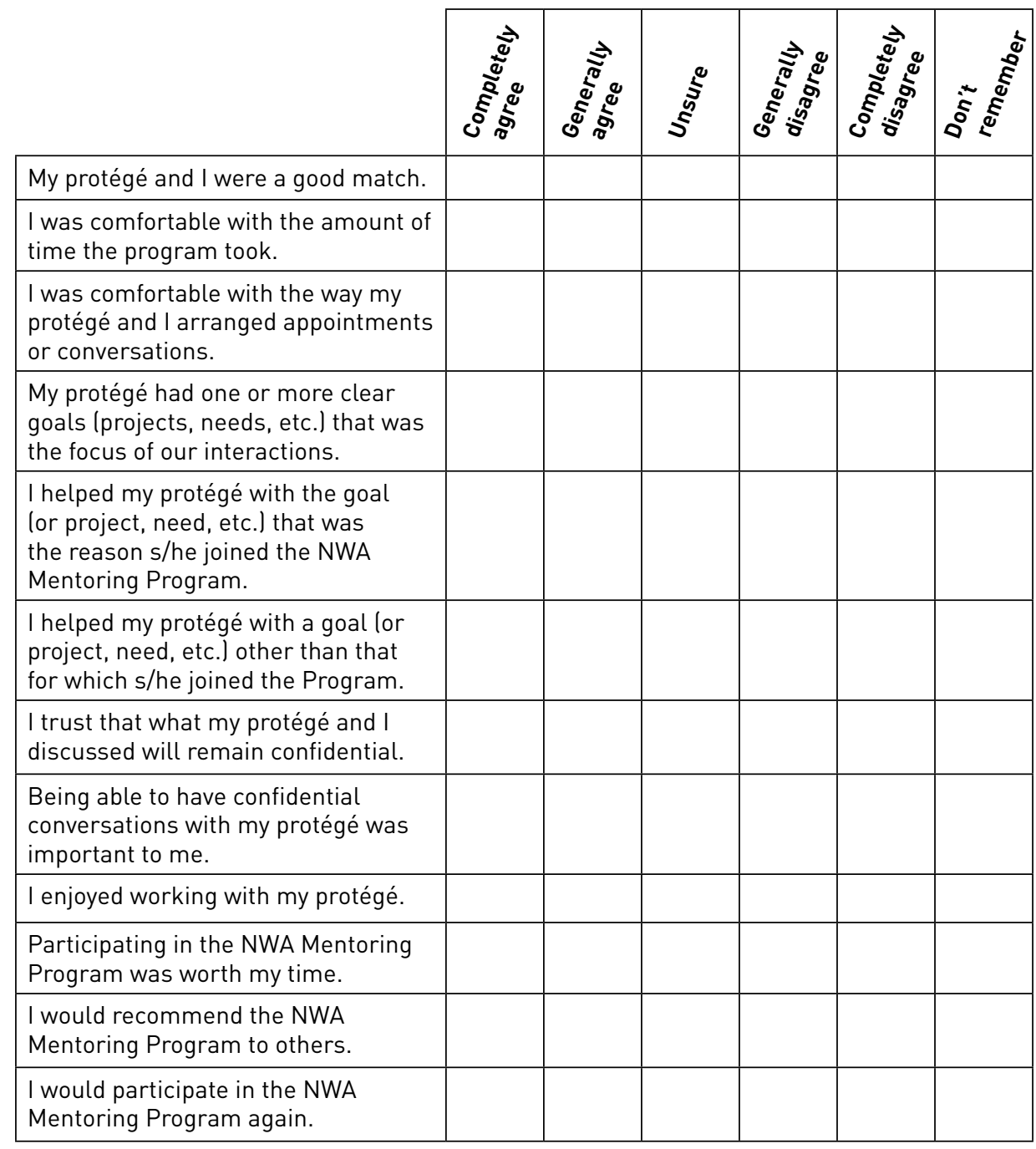

What role do you believe you filled for your protégé? [Check all that apply.]

$\square$ Teacher
$\square$ Advocate
$\square$ Counselor
$\square$ Resource
$\square$ Advisor
$\square$ Sponsor
$\square$ Other (please specify) [free text box]


The goal of the NWA Mentoring Program is to contribute to the success of NWA members by facilitating individual growth, fostering a sense of community within the profession, encouraging thoughtful and meaningful engagement with issues, and developing competencies that strengthen the position of individuals, organizations, and programs in our ever-changing environment.

Please indicate the degree to which you agree or disagree with the following statements:

\begin{tabular}{|l|l|l|l|l|}
\cline { 2 - 5 } & & & & \\
\hline $\begin{array}{l}\text { Participating in the NWA Mentoring } \\
\text { Program contributed to my professional } \\
\text { growth. }\end{array}$ & & & & \\
\hline $\begin{array}{l}\text { Participating in the NWA Mentoring } \\
\text { Program helped me feel more a part of } \\
\text { or more connected to the professional } \\
\text { community. }\end{array}$ & & & & \\
\hline $\begin{array}{l}\text { Participating in the NWA Mentoring } \\
\text { Program helped me have more thoughtful } \\
\text { and meaningful engagement with } \\
\text { professional issues. }\end{array}$ & & & & \\
\hline $\begin{array}{l}\text { Participating in the NWA Mentoring } \\
\text { Program helped me develop professional } \\
\text { competencies. }\end{array}$ & & & & \\
\hline $\begin{array}{l}\text { Participating in the NWA Mentoring } \\
\text { Program enhanced or improved my } \\
\text { impression of NWA. }\end{array}$ & & & & \\
\hline $\begin{array}{l}\text { Participating in the NWA Mentoring } \\
\text { Program contributed to my personal } \\
\text { growth. }\end{array}$ & & & & \\
\hline $\begin{array}{l}\text { NWA should continue to offer the } \\
\text { Mentoring Program. }\end{array}$ & & & & \\
\hline
\end{tabular}

What additional information about the NWA Mentoring Program do you wish you'd had? [free text box]

What additional information about mentoring in general do you wish you'd had or do you believe would be valuable to other mentors and potential mentors? [free text box]

How could the NWA Mentoring Program be improved for participants? [free text box] 
This is the NWA Mentoring Program's first “postmatch evaluation.” Please tell us what other question(s) should have been asked to gather useful feedback about the program. [free text box]

Please provide any additional feedback to the NWA Mentoring Committee. [free text box]

\section{Post-Match Protégé Survey}

Did you maintain contact with your mentor (as part of the official mentorprotégé match) for the whole 12 months of the match?

_ yes _ no _ don't remember

If your mentor-protégé contact ended before one year, how long did the contact last?
$\square 1$ conversation
$\square$ 1-2 months
$\square \quad 2-4$ months
$\square$ 4-6 months
$\square$ 6-11 months

If your mentor-protégé contact lasted less than 12 months, please indicate why (check all that apply).

$\square$ Unable to make or sustain contact with mentor.

$\square$ Goal or reason for wanting to work with a mentor was met or concluded.

$\square$ Goal or reason for wanting to work with a mentor changed.

$\square$ Mentor was not a good match for my need.

$\square$ Mentor was unable to assist me with my goal.

$\square$ The Mentoring Program was not the best way to help me meet my goal

$\square$ Other (please specify) [free text box].

How many times did you talk with your mentor in your role as a protégé (i.e. times that had been scheduled for the purpose of a mentor-protégé conversation)?

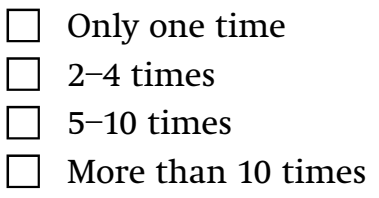

Do you feel this number of interactions was sufficient to address your reason(s) for joining the Mentoring Program?
_ yes no unsure $\mathrm{n} / \mathrm{a}$ 
How did you conduct the majority of your mentor-protégé interactions?

$\square$ By email

$\square$ By telephone

In person

$\square$ Other (please specify) [free text box]

Please share ideas about how the NWA Mentoring Program could better facilitate interactions between mentors and protégés. [free text box]

Indicate if you agree or disagree with the following statements:

\begin{tabular}{|l|l|l|l|l|l|}
\cline { 2 - 6 } \multicolumn{1}{l|l}{} & & & & & \\
\hline $\begin{array}{l}\text { I joined the NWA Mentoring Program } \\
\text { to get help with lor ideas related to) } \\
\text { a goal (such as a project, skill need, } \\
\text { advice, etc.). }\end{array}$ & & & & & \\
\hline $\begin{array}{l}\text { My mentor helped me with the goal } \\
\text { lor project, need, etc.) that was the } \\
\text { reason I joined the Program. }\end{array}$ & & & & & \\
\hline $\begin{array}{l}\text { My mentor helped me with a goal lor } \\
\text { project, need, etc.) other than that } \\
\text { for which I joined the Program. }\end{array}$ & & & & & \\
\hline
\end{tabular}

What role did your mentor fill for you? [check all that apply]

$\square$ Teacher

$\square$ Advocate

$\square$ Counselor

$\square$ Resource

$\square$ Advisor

Sponsor

Other (please specify) [free text box]

What outcomes resulted from or were enhanced by your interaction with your mentor? [check all that apply]

$\square$ New job, job change, or promotion

$\square$ New service or extensive revision of service

$\square$ New method or strategy

$\square$ Improved or expanded professional expertise

$\square$ Improved or expanded interactions with coworkers (including supervisors and direct reports)

$\square$ Conducting research

$\square$ Publication

$\square$ Presentation or poster 
$\square$ Grant writing or submission

$\square$ New or expanded service activities [i.e. community professional service or committee service or committee at your place of work]

$\square$ None

$\square$ Other (please specify) [free text box]

Indicate if you agree or disagree with the following statements:

\begin{tabular}{|c|c|c|c|c|c|c|}
\hline & 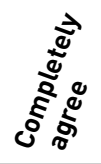 & 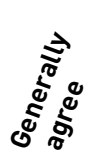 & $\frac{5}{5}$ & 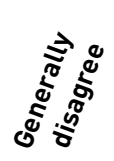 & 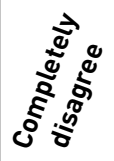 & : \\
\hline \multicolumn{7}{|l|}{ My mentor was accessible. } \\
\hline \multicolumn{7}{|l|}{$\begin{array}{l}\text { My mentor answered my } \\
\text { questions satisfactorily. }\end{array}$} \\
\hline \multicolumn{7}{|l|}{$\begin{array}{l}\text { My mentor suggested } \\
\text { appropriate resources. }\end{array}$} \\
\hline \multicolumn{7}{|l|}{$\begin{array}{l}\text { My mentor demonstrated } \\
\text { professional integrity. }\end{array}$} \\
\hline \multicolumn{7}{|l|}{$\begin{array}{l}\text { My mentor was supportive and } \\
\text { encouraging. }\end{array}$} \\
\hline \multicolumn{7}{|c|}{$\begin{array}{l}\text { My mentor challenged me to extend } \\
\text { my abilities. }\end{array}$} \\
\hline \multicolumn{7}{|c|}{ My mentor and I were a good match. } \\
\hline \multicolumn{7}{|c|}{$\begin{array}{l}\text { I was comfortable with the way my } \\
\text { mentor and I arranged appointments } \\
\text { or conversations. }\end{array}$} \\
\hline \multicolumn{7}{|c|}{$\begin{array}{l}\text { Being able to have confidential } \\
\text { conversations with my mentor was } \\
\text { important to me. }\end{array}$} \\
\hline \multicolumn{7}{|c|}{$\begin{array}{l}\text { I trust that what my mentor and } \\
\text { I discussed will remain confidential. }\end{array}$} \\
\hline \multicolumn{7}{|c|}{ I enjoyed working with my mentor. } \\
\hline \multicolumn{7}{|c|}{$\begin{array}{l}\text { I would feel comfortable seeking } \\
\text { advice or input from my mentor in } \\
\text { the future. }\end{array}$} \\
\hline \multicolumn{7}{|c|}{$\begin{array}{l}\text { I was comfortable with the amount } \\
\text { of time the program took. }\end{array}$} \\
\hline \multicolumn{7}{|l|}{$\begin{array}{l}\text { Participating in the mentoring } \\
\text { program was worth my time. }\end{array}$} \\
\hline \multicolumn{7}{|l|}{$\begin{array}{l}\text { I would recommend the NWA } \\
\text { Mentoring Program to others. }\end{array}$} \\
\hline $\begin{array}{l}\text { I would participate in the NWA } \\
\text { Mentoring Program again. }\end{array}$ & & & & & & \\
\hline
\end{tabular}


The goal of the NWA Mentoring Program is to contribute to the success of NWA members by facilitating individual growth, fostering a sense of community within the profession, encouraging thoughtful and meaningful engagement with issues, and developing competencies that strengthen the position of individuals, organizations, and programs in our everchanging environment.

Please indicate the degree to which you agree or disagree with the following statements:

\begin{tabular}{|l|l|l|l|l|}
\cline { 2 - 5 } & & & & \\
\hline $\begin{array}{l}\text { Participating in the NWA Mentoring } \\
\text { Program contributed to my professional } \\
\text { growth. }\end{array}$ & & & & \\
\hline $\begin{array}{l}\text { Participating in the NWA Mentoring } \\
\text { Program helped me feel more a part of } \\
\text { or more connected to the professional } \\
\text { community. }\end{array}$ & & & & \\
\hline $\begin{array}{l}\text { Participating in the NWA Mentoring } \\
\text { Program helped me have more thoughtful } \\
\text { and meaningful engagement with } \\
\text { professional issues. }\end{array}$ & & & & \\
\hline $\begin{array}{l}\text { Participating in the NWA Mentoring } \\
\text { Program helped me develop professional } \\
\text { competencies. }\end{array}$ & & & & \\
\hline $\begin{array}{l}\text { Participating in the NWA Mentoring } \\
\text { Program enhanced or improved my } \\
\text { impression of NWA. }\end{array}$ & & & & \\
\hline $\begin{array}{l}\text { Participating in the NWA Mentoring } \\
\text { Program contributed to my personal } \\
\text { growth. }\end{array}$ & & & & \\
\hline $\begin{array}{l}\text { NWA should continue to offer the } \\
\text { Mentoring Program. }\end{array}$ & & & & \\
\hline
\end{tabular}

How could the NWA Mentoring Program be improved for participants? [free text box]

This is the NWA Mentoring Program's first "postmatch evaluation." Please tell us what other question(s) should have been asked to gather useful feedback about the program. [free text box]

Please provide any additional feedback to the NWA Mentoring Committee. [free text box] 


\section{Notes}

The authors are grateful to the NWA members, including the 2007 NWA Board, who reviewed and strengthened the original NWA Mentoring Program proposal, and to the mentors and protégés who participated in the program and provided valuable feedback. We are also grateful to the reviewers of the draft of this article for their comments and suggestions.

1 Northwest Archivists, Inc., "About NWA," http://northwestarchivistsinc.wildapricot.org/about.

2 The importance of trust in a mentoring relationship is a recurring theme throughout the literature. The specific importance of confidentiality is discussed in Dennis J Moberg and Manuel Velesquez, “The Ethics of Mentoring,” Business Ethics Quarterly 14, no. 1 (2004): 95-122.

3 Emphasis on benefits for mentors can be found in Margo Murray, Beyond the Myths and Magic of Mentoring: How to Facilitate an Effective Mentoring Process (San Francisco, Calif.: Jossey-Bass, Inc., 2001), 39; Timothy Newby and Ashlyn Heide, “The Value of Mentoring," Performance Improvement Quarterly 26, no. 2 (2013): 141-58; Robert Morison, Tamara Erickson, and Ken Dychtwald, "Managing Middlescence," Harvard Business Review (March 2006): 75-86; Rajashi Ghosh and Thomas G. Reio Jr., “Career Benefits Associated with Mentoring for Mentors: A Meta-Analysis,” Journal of Vocational Behavior 83 (2013): 106-16.

4 Sharon Howe, email to member and to Donna McCrea, November 13, 2006. Concerns with the relevance of the SAA program to NWA members included perceived desire for mentors located within NWA's geographical region and perceived lack of SAA mentors with experience managing multiple aspects of archival work, as is common among NWA members.

5 Particular thanks are due to Dr. Mary Bushing for information about a proposed Mountain Plains Library Association mentoring program, to Adriana Cuervo for information about the Society of American Archivists' mentoring program, and to Samantha Schmehl Hines, who provided an early draft of her article "Adventures in Online Mentoring: The New Members' Roundtable Career Mentoring Program," which was published in the Journal of Web Librarianship 1 (2007): 51-65.

6 Barbara Wittkopf, Mentoring in ARL Libraries: Spec Kit 239 (Washington, D.C.: Association of Research Libraries, 1999).

7 Lois J. Zachary, The Mentor's Guide: Facilitating Effective Learning Relationships (San Francisco, Calif.: John Wiley and Sons, Inc., 2000).

8 Bonnie A. Osif, "Successful Mentoring Programs: Examples from Within and Without the Academy," Journal of Business and Finance Librarianship 13 (2008): 335-47.

9 Norman H. Cohen, A Step-by-Step Guide to Starting an Effective Mentoring Program (Amherst, Mass.: HRC Press, 2000).

${ }^{10}$ Murray, Beyond the Myths and Magic of Mentoring.

${ }^{11}$ Wittkopf, Mentoring in ARL Libraries.

${ }^{12}$ Zachary, The Mentor's Guide. A number of valuable additional resources have been published or come to the authors' attention following the development of the NWA program, including those available at the National Mentoring Partnership website, http://www.mentoring.org and in Tammy D. Allen et al., "The State of Mentoring Research: A Qualitative Review of Current Research Methods and Future Research Implications," Journal of Vocational Behavior 73 (2008): 343-57.

${ }^{13}$ Cohen, A Step-by-Step Guide, 7.

${ }^{14}$ Donna McCrea, "Mentoring Program for Northwest Archivists, Inc.," Easy Access: Newsletter of the Northwest Archivists 33, no 2 (2007): 14.

${ }^{15}$ Shin Freedman, “Effective Mentoring,” IFLA Journal 35, no. 2 (2009): 171-82.

${ }^{16}$ An official coordinator role is a component of all formal corporate mentoring programs.

${ }^{17}$ Protégé goal setting is discussed in Murray, Beyond the Myths and Magic of Mentoring.

${ }^{18}$ The option of meeting or approving the mentor in advance of the formal match is advocated in Mentoring the Next Generation of Nonprofit Leaders: A Practical Guide for Managers (Washington, D.C.: AED, Center for Leadership Development, 2005), 9, http://cld.aed.org/PDF/MentoringNextGeneration .pdf.

19 This "no-fault conclusion" was based on recommendations by Murray, Beyond the Myths and Magic of Mentoring, 172, and Mentoring the Next Generation of Nonprofit Leaders, 29. 
${ }^{20}$ The need to evaluate program effectiveness is discussed in Murray, Beyond the Myths and Magic of Mentoring, 160-72; formative and summative evaluations are discussed in MacGregor Kniesley, Knowing You've Made a Difference: Strengthening Campus-Based Mentoring Programs through Evaluation and Research (Denver: Education Commission of the States; Providence: Campus Compact, Brown University, 1990), 12-13. We are grateful to these authors for permission to borrow from their language for our postmatch survey: Diana Farmer, Marcia Stockham, and Alice Trussell, "Revitalizing a Mentoring Program for Academic Librarians," College and Research Libraries 70, no. 1 (2009): 8-25.

${ }^{21}$ The language of the survey was drawn, in part, from Farmer et al., "Revitalizing a Mentoring Program for Academic Librarians," 8-25.

${ }^{22}$ Northwest Archivists, Inc,. "NWA Strategic Planning Survey Results," http://northwestarchivistsinc .wildapricot.org/StrategicPlanning.

${ }^{23}$ Opportunities for substantive partnerships between the Society of American Archivists and the regional associations were discussed in Session 606 at the 75th Annual Meeting of Society of American Archivists in 2011 and summarized in Danna C. Bell-Russel et al., "Session 606: E Pluribus Unum? SAA and the Regionals,” The American Archivist 74, supplement (2011), http://www2 .archivists.org/sites/all/files/AAOSv074-Session606.pdf.

${ }^{24}$ Zachary, The Mentor's Guide, 34.

${ }^{25}$ Program evaluation is addressed by Murray, Beyond the Myths and Magic of Mentoring, 160-72.

\section{ABOUT THE AUTHORS}

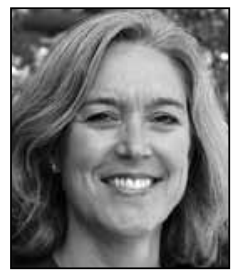

Donna E. McCrea is a tenured professor and head of archives and special collections at the University of Montana, Missoula, where she has worked since 2003. Her research interests include mentoring, leadership development, and course-integrated instruction. She has served on the SAA Committee on Education and the SAA Council, and served as the NWA mentoring program coordinator from 2007-2011. She received her MLIS from the University of Wisconsin-Milwaukee in 1999.

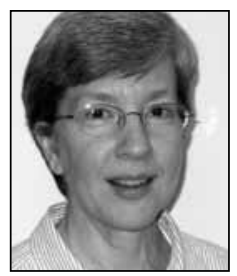

Elizabeth A. Nielsen is university archivist in the Oregon State University Special Collections and Archives Research Center. She earned a BS in geology and BA in mathematics from Southern Methodist University in 1980 and an MA in geology from the University of California at Santa Barbara in 1982. During the 1980s, Nielsen studied historic volcanic eruptions as a geologist with the Smithsonian Institution and the U.S. Geological Surveywork that introduced her to the archival enterprise. She joined the staff of the Oregon State University Archives in 1990 and was appointed university archivist in 2014. In addition to records management, her primary archival responsibility is oversight of the center's arrangement and description program. Nielsen has been an active member of Northwest Archivists since the early 1990s and was chair of the Northwest Archivists Mentoring Committee from 2007 to 2011.

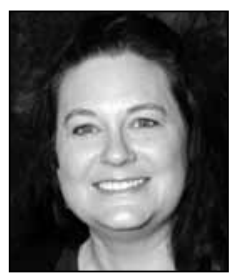

Anne Foster is the archivist for Yellowstone National Park. She earned a BA in history from Montana State University and a MLS with a concentration in archives from the University of Maryland at College Park. Foster has previously worked for academic, local history, and state government repositories in Alaska, Arizona, Colorado, and Montana. She has been a member of Northwest Archivists since 2000, and is the current mentoring program coordinator. 